\title{
簡単な操作で作製された焼成ホタテガイ貝殼ーガラス複合成形体 の抗菌・抗カビ効果
}

\author{
三原義広 - 高田知哉 - 宇野直嗣 - 富樫 巌 - 杉本敬祐 \\ 旭川工業高等専門学校， 071-8142 旭川市春光台2-2-1-6
}

\section{Antibacterial and antifungal effects of fired scallop shell - glass composites fabricated by a simple process}

\author{
Yoshihiro MIHARA, Tomoya TAKADA, ${ }^{\dagger}$ Naotsugu UNO, Iwao TOGASHI and Keisuke SUGIMOTO
}

Asahikawa National College of Technology, 2-2-1-6, Syunkodai, Asahikawa 071-8142

\begin{abstract}
Antibacterial and antifungal effects of fired scallop shell - glass composites have been examined. The composites were fabricated by the following simple process: (1) mixing the powder mixture of fired shell, raw shell and glass with aqueous NaOH solution, (2) first drying, (3) steam treatment, and (4) second drying. In this study, the powder mixtures with the shell (fired shell + raw shell) : glass weight ratios of $1: 1$ have been employed as raw materials. It has been found that the composites are successfully hardened when the fired shell contents in the original powder mixture is less than 35 mass\%. Antibacterial and antifungal effects of the composites were tested for Escherichia coli and Cladosporium sp.. It has been found that the composites with relatively high content of fired shell ( $\geq 20$ mass\% for Escherichia coli and $\geq 25$ mass\% for Cladosporium sp.) show significant antibacterial and antifungal effects.
\end{abstract}

๑2008 The Ceramic Society of Japan. All rights reserved.

Key-words : Scallop shell, Glass, Composite, Escherichia coli, Cladosporium sp., Antibacterial effect, Antifungal effect

[Received April 2, 2008; Accepted June 19, 2008]

\section{1. 緒 言}

日本におけるホタテガイの主な産地は北海道・東北地域で あり，これらの地域ではホタテガイは重要な水産資源である. しかし，加工業者がホタテガイを加工したあとに残る貝殼は 非常に大量であり，多くの自治体等から有効な利用が求めら れているものである．例えば北海道では，年間およそ 20 万卜 ン程度のホタテガイ貝殼（以下，貝殼と表記する）が排出さ れており, その一部は浄水材, 暗渠疎水材, 養鷄飼料等とし て利用されるものの，半分以上は利用されずに産業廃棄物と なる.

貝殼の保管方法は, 多くの場合は屋外にて堆積させた状態 での保管である。しかし，この方法には，特有の悪臭の発生， 有機組織の腐敗で生じる液状成分による土袞污染, 保管用地 の確保といった問題がある.

これらのことを解決するため, 貝殼の再利用・製品化のた めの研究開発が盛んに行なわれてきた。 その一つとして, 焼 成した貝殼の抗菌性に関する研究がある. 吉田らによれば, 焼 成した貝殼を含む水溶液は大腸菌, 黄色ブドウ球菌, サルモ ネラ菌, 白癬菌, ミュータンス菌, メシチリン耐性黄色ブド ウ球菌に対する抗菌効果を示すことがわかっている ${ }^{1)}$. しか し, 他の成分を含む固体材料に取り込まれた条件での焼成貝

Corresponding author: T. Takada; E-mail: takada@asahikawa-nct. ac.jp
殼の抗菌性については, 詳しい研究例はない.

固体材料では焼成貝殼が他の成分に取り囲まれた状態とな るため, 焼成貝殼本来の抗菌効果が現れないことが考えられ る. しかし, 焼成貝殼を含む固体材料が水溶液と同様な抗菌 性を示すことが証明できれば, 抗菌性材料としての貝殼の再 利用につながる. さらに, 特殊な薬剤, 過酷な条件, 複雑な 操作などを含まない簡単な材料製造法を確立できれば，低コ ストでの事業化が可能となるため, 貝殻の処理に迫られる地 域での新産業の創出に貢献できる.

本研究では, 焼成貝殼と廃ガラスの粉体混合物を原料とし た複合成形体の作製法を確立し, その抗菌・抗力ビ効果を評 価することを目的とした，家屋や自動車の解体で生じる廃ガ ラスも, 貝殼同様に再利用が望まれる廃棄物の一つである. 本 研究では, 粉体混合物を水酸化ナトリウムと混合してガラス を溶解させ, 乾燥 - 固化させたのち水蒸気処理にて硬化させ る方法で, ガラスをバインダーとして焼成貝殼を固定化した 複合成形体の作製を試みた。この方法によれば，任意の形状 の材料を得ることが可能であり, 抗菌・抗力ビ効果を維持し たまま成形体を作製することができれば，抗菌性材料として広 範な用途に用いることができる. 本研究では, 原料粉体の重量 比を様々に変化させて成形体を作製し, それらの抗菌・抗力 ビ効果を比較した. 対象とした菌・カビは, 大腸菌 (Escherichia coli）とクロカビ（Cladosporium sp.）である. 


\section{2. 実 験}

\section{1 複合成形体の作製}

貝殼は, 北海道宗谷地方産のホタテガイから得られたもの を右殼・左殼を区別せずに使用した。貝殼の調達に際しては, 貝柱や内臟等の有機組織が除かれた状態のものを入手した. 貝殸をジョークラッシャーまたはハンマーで粗く砕いたのち ボールミルで粉体とし, ふるい分けにより $0.125 \mathrm{~mm}$ 以下の粒 径のものを選別して原料とした。粉砕した貝殼を, 空気中 $1000^{\circ} \mathrm{C}$ にて 24 時間焼成し, 焼成貝殼粉体を得た.

ガラスは，建築廃材から得られた透明空ガラスを使用した (ガラスの成分の同定は行なっていない). 貝殼と同様の方法 で, ガラスも粗粉砕・ボールミル粉砕を行って粉体とし, ふ るい分けによって $0.125 \mathrm{~mm}$ 以下の粒径のものを選別し使用 した.

未焼成の貝殼粉体, 焼成貝殼粉体, ガラス粉体を混合し, 原 料粉体を調製した. 貝殼粉体（未焼成貝殼十焼成貝殼）とガ ラス粉体の重量比は 1:1 とし, 焼成貝殼粉体の重量パーセン トは原料粉体全体の 0 〜 50 mass\% とした.

原料粉体 $60 \mathrm{~g}$ に, $2 \mathrm{~mol} \mathrm{dm}^{-3}$ 水酸化ナトリウム水溶液を 20 $\mathrm{g}$ 加えて混合し, スラリー状の混合物を調製した。この混合物 を, 幅 $100 \mathrm{~mm} \times$ 奥行 $80 \mathrm{~mm} \times$ 高さ $10 \mathrm{~mm}$ のステンレス製の 型枠または $20 \mathrm{~mm}$ 四方 $\times$ 高さ $5 \mathrm{~mm}$ のプラスチックトレーに 流し込み, 空気中室温にて静置し乾燥・成形した。 得られた 成形体を常圧下にて $100^{\circ} \mathrm{C}$ の水蒸気に 8 時間曝すことで硬化 させた.

\section{2 原料および複合成形体の成分の同定}

未焼成貝殼および焼成貝殼の成分を同定するため, RIGAKU RAD-B を用いて粉末 X 線回折 (XRD) 測定を行った. 測定に は $\mathrm{Cu} \mathrm{K} \alpha$ 線を用いた。成分の同定は, JCPDS カードに記載の データとの比較により行った ${ }^{2)}$. 同様の方法で, 作製した成形 体を粉砕したのち XRD 測定を行い, 成形処理前後の成分を比 較した.

\section{3 複合成形体の抗菌・抗力ビ効果の評価}

大腸菌 (E. coli) に対する抗菌性は, 以下の方法で評価し た. E. coli NBRC 3972 株（以下では大腸菌と表記）を接種し た PDA 寒天培地の表面中央に $20 \mathrm{~mm}$ 四方の底面積の成形体 を載せ, $30^{\circ} \mathrm{C} に て 36$ 時間培養した後の阻止円（成形体の周 囲において菌の成長が阻止される範囲）のサイズを測定し た。阻止円の定義を図 1 に示す. 培地の中央に載せた成形体 の各辺から阻止円の外周までの距離を, 各辺 4 点ずつ計 16 点 測定し，それらを平均した距離を阻止円の範囲とした。対照 実験として, 成形体の代わりに成形体と同じ底面積を有する ガラス板を用いた測定を行った.

クロカビ（Cladosporium sp.）に対する抗力ビ性は, 以下の 方法で評価した. Cladosporium sp. ANCT-05065 株 (旭川工業 高等専門学校校舎内で採取した落下菌, 以下ではクロカビと 表記）を接種した GP 液体培地 $9 \mathrm{~cm}^{3}$ に成形体を $1 \mathrm{~g}$ 加え, $25^{\circ} \mathrm{C}$ で 7 日間培養した後, 生成したクロカビの菌体を沪過・ 乾燥し重量を測定した。対照実験として, 成形体を入れていな い pH7 の培地 (negative control) と, 成形体を入れずに水酸化 ナトリウムを用いて培地の $\mathrm{pH}$ を 12 に調整した培地 (positive control）を用いて, 同様の培養および重量測定を行った。 ま た，培養後には各液体培地の $\mathrm{pH}$ 測定を行った。

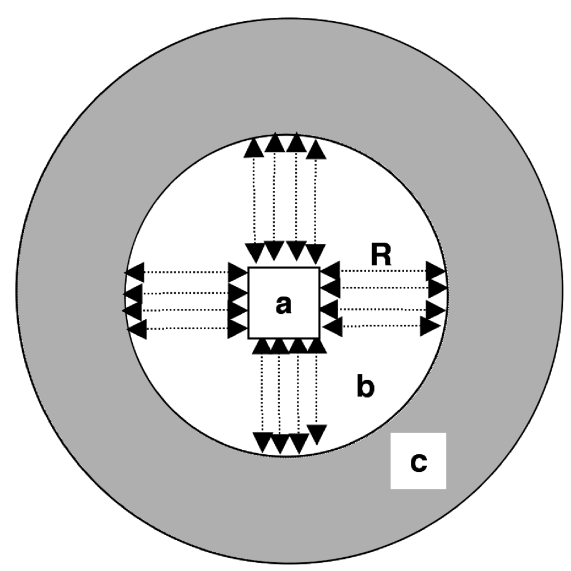
a: composite
b: halo
c: E.coli

Fig. 1. Definition of halo for E. coli antibacterial test. The symbol R represents the distance between the edges of composite and halo.

\section{3. 結果と考察}

\section{1 複合成形体に含まれる成分と強度}

原料である未焼成貝殼と焼成貝殼の XRD パターンを図 2 に示す．既に知られている通り，未焼成貝款は炭酸カルシウ ム $\left(\mathrm{CaCO}_{3}\right.$, カルサイト) が主成分であり, これに加えて少量 のタンパク質などを含む. これを $1000^{\circ} \mathrm{C}$ にて加熱した焼成貝 殼には $\mathrm{CaCO}_{3}$ は含まれず, 酸化カルシウム $(\mathrm{CaO})$ と少量の 水酸化カルシウム $\left(\mathrm{Ca}(\mathrm{OH})_{2}\right)$ が主成分となる. $\mathrm{CaCO}_{3}$ からの 脱炭酸により $\mathrm{CaO}$ が生じ, 続いて一部の $\mathrm{CaO}$ と空気中の水と の反応により $\mathrm{Ca}(\mathrm{OH})_{2}$ が生じたことがわかる.

$$
\begin{aligned}
& \mathrm{CaCO}_{3} \rightarrow \mathrm{CaO}+\mathrm{CO}_{2} \\
& \mathrm{CaO}+\mathrm{H}_{2} \mathrm{O} \rightarrow \mathrm{Ca}(\mathrm{OH})_{2}
\end{aligned}
$$

$$
\begin{array}{ll} 
& \mathrm{CaCO}_{3} \\
& \mathrm{CaO} \\
& \mathrm{Ca}(\mathrm{OH})_{2} \\
& \text { other components }
\end{array}
$$

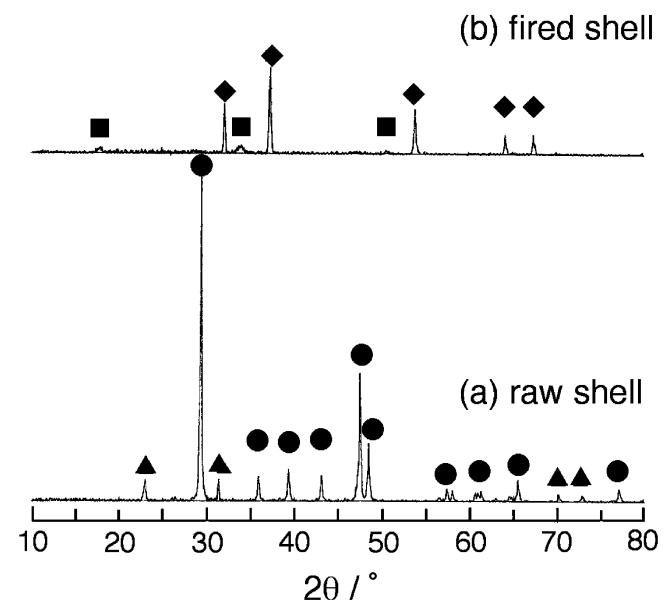

Fig. 2. Powder XRD patterns of raw and fired scallop shells. (a) raw shell, (b) fired shell. 
予備的な強度の評価（重しを用いた 3 点法による曲げ強度 試験) ${ }^{3)}$ によれば，原料粉体全体（未焼成貝殼十焼成貝殼十ガ ラス) に占める焼成貝殼の重量が 0-35 mass\% の場合に十分な 強度を有する成形体が得られ, 焼成貝殼の含有量がこの範囲 を超える場合では十分な強度が得られなかった（原料粉体が 凝集している状態にとどまり，脆い成形体となった）。以下， 焼成貝殼含有量が $x[$ mass\%] の原料粉体から作製した成形体を $\mathrm{C}(x)$ と表記する。厚さ $1 \mathrm{~cm}$ あたりの曲げ破壊荷重は, $\mathrm{C}(0)$ で 約 $200 \mathrm{~N} / \mathrm{cm}, \mathrm{C}(35)$ では約 $100 \mathrm{~N} / \mathrm{cm}$ であり, 焼成貝殼含有量 が多くなるほど破壊荷重は低下した。

成形体の XRD パターンの例として, C(35) の XRD パターン を図 3 に示す。また, XRD により確認されたすべての組成の 成形体 $(C(0-50))$ の成分を表 1 に示す. $C(\leq 20)$ では成分とし て $\mathrm{CaCO}_{3}$ のみが確認された. $\mathrm{C}(0)$ では, 未焼成貝殼の成分で ある $\mathrm{CaCO}_{3}$ がそのまま成形体中に含まれ, 他の成分には変化 していない，C(5-20) では焼成貝殸含有量が少量であるため, XRD ではその成分が検出されなかったものと考えられる. $\mathrm{C}(25-40)$ では, $\mathrm{CaCO}_{3}, \mathrm{CaO}$ および $\mathrm{Ca}(\mathrm{OH})_{2}$ が確認された. 原料粉体に含まれる $\mathrm{CaO}$ が成形処理中の水と反応して $\mathrm{Ca}(\mathrm{OH})_{2}$ に変化し, $\mathrm{CaCO}_{3}, \mathrm{CaO}$ および $\mathrm{Ca}(\mathrm{OH})_{2}$ を含んだものとなっ たことがわかる. 従って, この成形体は水酸化ナトリウムの 作用によって溶解したガラスがバインダーとなって $\mathrm{CaCO}_{3}$, $\mathrm{CaO}$ および $\mathrm{Ca}(\mathrm{OH})_{2}$ の粒子を接合しているものと考えられ る. $\mathrm{C}(\geq 45)$ では成分として $\mathrm{CaO}$ および $\mathrm{Ca}(\mathrm{OH})_{2}$ が確認され
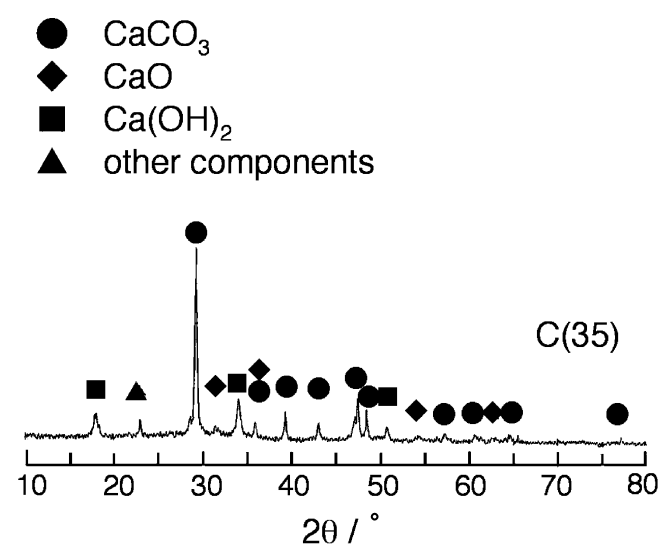

Fig. 3. Powder XRD pattern of $\mathrm{C}(35)$.

Table 1. Components of Composites Detected by XRD Measurements

\begin{tabular}{cl}
\hline Composite & Detected component \\
\hline $\mathrm{C}(0)$ & $\mathrm{CaCO}_{3}$ \\
$\mathrm{C}(5)$ & $\mathrm{CaCO}_{3}$ \\
$\mathrm{C}(10)$ & $\mathrm{CaCO}_{3}$ \\
$\mathrm{C}(15)$ & $\mathrm{CaCO}_{3}$ \\
$\mathrm{C}(20)$ & $\mathrm{CaCO}_{3}$ \\
$\mathrm{C}(25)$ & $\mathrm{CaCO}_{3}, \mathrm{CaO}, \mathrm{Ca}(\mathrm{OH})_{2}$ \\
$\mathrm{C}(30)$ & $\mathrm{CaCO}_{3}, \mathrm{CaO}, \mathrm{Ca}(\mathrm{OH})_{2}$ \\
$\mathrm{C}(35)$ & $\mathrm{CaCO}_{3}, \mathrm{CaO}, \mathrm{Ca}(\mathrm{OH})_{2}$ \\
$\mathrm{C}(40)$ & $\mathrm{CaCO}_{3}, \mathrm{CaO}, \mathrm{Ca}(\mathrm{OH})_{2}$ \\
$\mathrm{C}(45)$ & $\mathrm{CaO}, \mathrm{Ca}(\mathrm{OH})_{2}$ \\
$\mathrm{C}(50)$ & $\mathrm{CaO}, \mathrm{Ca}(\mathrm{OH})_{2}$ \\
\hline
\end{tabular}

た. $\mathrm{C}(45)$ では未焼成貝殼含有量が少量であるため, $\mathrm{CaCO}_{3}$ が 検出されなかったものと考えられる.

$100^{\circ} \mathrm{C}$ の水蒸気に曝す操作は, 建材の製造における水蒸気養 生に相当する. しかし, この場合の水蒸気処理は, 例えば既 に報告されているようなケイ酸カルシウムの生成 ${ }^{4)}$ を促進す るわけではなく, 処理の前後で成分は変化していない。この 場合の水蒸気処理の効果は, 成形体の空隙に水蒸気が入り込 むことによって, 水酸化ナトリウムによるガラスの溶解を促 進し, 成形体全体にガラスを行き渡らせることにより強度を 向上させるものと考えられる. 本研究では廃材由来のガラス を用いたため, ソーダ石灰ガラスが主成分として含まれると 考えられるが，正確な同定は現時点では行なっていない. ガ ラスの成分による硬化挙動の違いは, 今後の検討課題である.

\section{2 大腸菌およびクロカビに対する各成形体の抗菌・ 抗力ビ効果}

成形体の焼成貝殼含有量と, 阻止円の範囲の関係を図 4 に 示す. 焼成貝殼の含有量の多い成形体ほど, 大腸菌の生育を 抑制する効果が高いことがわかった． C $(\leq 15)$ を用いた試験で は阻止円がみられず, 大腸菌に対する効果が認められなかっ た.これに対して, $\mathrm{C}(\geq 20)$ では焼成貝殼含有量の増加ととも に阻止円を拡張する効果が顕著となった. 緒言にて述べた通 り, 焼成貝殼を水溶液にしたものが種々の菌に対して抗菌効 果を示すことは既に知られているが ${ }^{1)}$, 上記の結果から, 成形 体に混合された状態においても焼成貝殼は抗菌効果を示すこ とが明らかになった。 なお, 対照実験では抗菌効果は認めら れなかった。

クロカビを接種した GP 液体培地の写真を図 5 に示す. 図 中で, PC と表記されている試料は positive control であり, NC

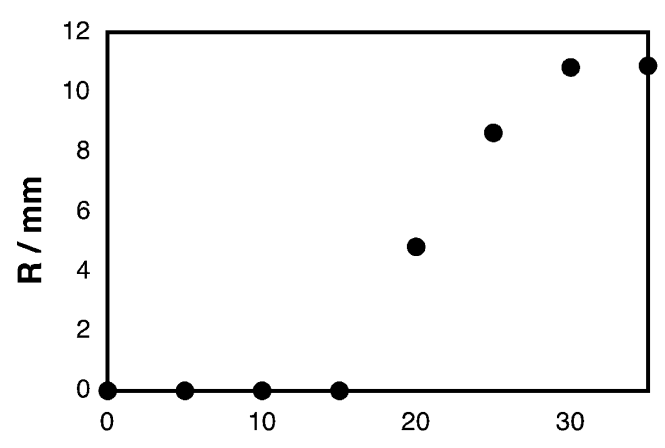

Fired shell content / mass \%

Fig. 4. Mean distance $\mathrm{R}$ on halo as a function of fired shell content of composites used.

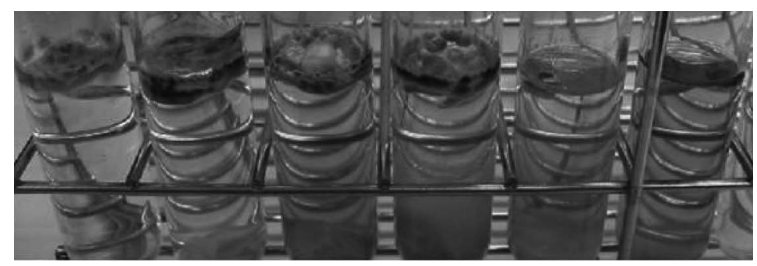
(a) (b)
NC $\mathrm{C}(0)$
(c)
(d)
(e) (f) C(25) $\quad C(35)$
C(50) PC

Fig. 5. Photograph of the GP liquid media containing Cladosporium $s p$. (a) negative control (NC); (b)-(e) liquid media with $\mathrm{C}(0), \mathrm{C}(25)$, $\mathrm{C}(35), \mathrm{C}(50)$, respectively; (f) positive control (PC). 


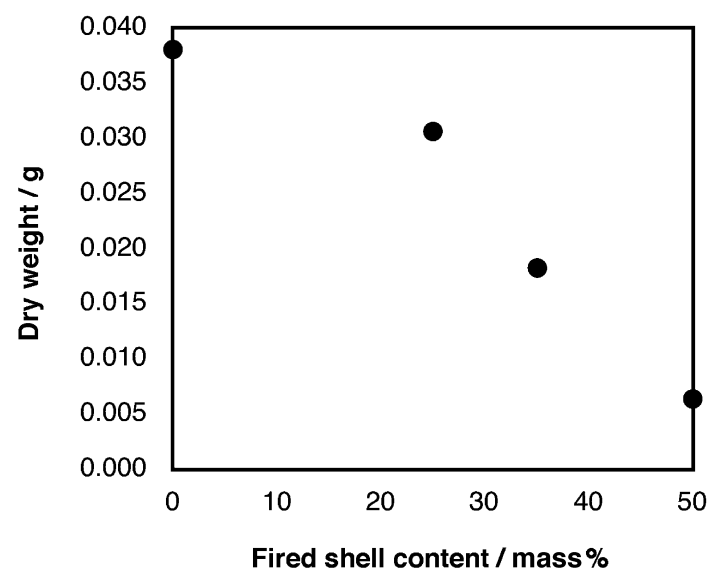

Fig. 6. Dry weight of grown Cladosporium $s p$. as a function of fired shell content of composites used.

と表記されている試料は negative control である.この試験で は，焼成貝殼含有量による抗力ビ性の違いを比較するため, 強度の低い $\mathrm{C}(50)$ による試験も行った。写真は接種後 7 日を 経た培地であり，液面にクロカビが生成していることがわか る. $25^{\circ} \mathrm{C}$ で 7 日間培養した後に生成したクロカビの乾燥重量 と, 使用した成形体の焼成貝殼含有量の関係を図 6 に示寸. $\mathrm{PC}$ および $\mathrm{C}(\geq 25)$ を入れた培地では, 成形体の焼成貝殼含有 量の増加に伴い生成するクロカビの重量が減少し, 生育を抑 制する効果がみられた. $\mathrm{NC}$ および $\mathrm{C}(\leq 20)$ を入れた培地で は, クロカビの生育を抑制する効果がみられなかった。

PC ではクロカビの生育を抑制する効果がみられたが, 水酸 化ナトリウムによる菌類の生育の抑制効果は既に知られてい る. 本研究で用いた液体培地の培養後の $\mathrm{pH}$ を測定すると, $\mathrm{NC}$ では pH5.9, 抗力ビ効果のみられなかった培地では最大で pH9.6 程度であった. 対して, PCでは pH10.5, 抗力ビ効果の みられた培地では $\mathrm{pH} 10.7$ 以上であった。 このことから, 本研 究で作製した成形体の抗力ビ効果には, 成形体に含まれるア ルカリ成分が関与していると推測される.
以上の結果から，焼成貝殼は成形体中にてガラスと混合し ている状態でも抗菌・抗力ビ効果を示すことが明らかとなっ た．本研究の条件にて作製した成形体では，焼成貝殼の成分 が成形体外の培地と接触し効果を及ぼすための空孔が保持さ れていたと考えられる。焼成貝款による抗菌・抗力ビ効果の 発現機構としては, アルカリ成分 $\left(\mathrm{OH}^{-}\right.$イオン) による細胞 への栄養素取り込みの阻害作用 ${ }^{1)}$ のほか， $\mathrm{CaO}$ に起因する $\mathrm{O}_{2}^{-}$イオンによる殺菌作用 ${ }^{5)}$ などが考えられるが, 詳しい発現 機構については更なる検討を要する.

\section{4.まとめ}

本研究では, 廃棄物であるホタテガイ貝殸とガラスを再利 用し，抗菌・抗カビ効果を有する複合成形体を作製した。未 焼成貝殼, 焼成貝殼およびガラスを混合した粉体に水酸化ナ トリウムを加え, 乾燥させたのち水蒸気にて硬化処理を施す ことにより, 大腸菌およびクロカビに対して抗菌・抗力ビ効 果を示す成形体を得ることができた。

この成形体の作製は, 貝殼の焼成と水蒸気処理を除いて常 温・大気圧のもとで行なうことができ, 処理に必要な薬剤も 水酸化ナトリウムのみであるため, 簡単な操作であるといえ る. また, スラリー状の混合物を用いて成形を行うため, 形 状を自由に選択できることも利点として挙げられる. 今後, 本 研究で作製した成形体がさまざまな場面で用いられ, 北海道・ 東北地域での新産業創出に寄与寸ることを期待する.

なお, 本研究の成果は特許出願済である ${ }^{6)}$.

\section{References}

1) T. Yoshida et al., Hachinohe Kogyo Daigaku Ibunya Yugou Kagaku Kenkyujo Kiyou, 1, 117-120 (2003) [in Japanese].

2) JCPDS data: 7-763 $\left(\mathrm{CaCO}_{3}\right), 28-775(\mathrm{CaO})$ and 4-733 $\left(\mathrm{Ca}(\mathrm{OH})_{2}\right)$

3) JIS Z2204, 226.

4) E. Sakai et al., Japan Patent No. 2007-131488 [in japanese].

5) J. Sawai et al., Bokin Bobai, 34, 65-71 (2006) [in Japanese].

6) T. Takada et al., Japan Patent Pending No. 2007-54910 [in Japanese]. 